\title{
THE IMPACT OF TOURISM TOWARDS SUSTAINABILITY AND THE CHANGE OF ARCHITECTURE
}

\author{
Rachmat Budihardjo ${ }^{1}$, Rumiati R.Tobing ${ }^{2}$, Antariksa ${ }^{3}$ \\ ${ }^{1}$ Parahyangan Catholic University - Bandung, Indonesia \\ ${ }^{2}$ Parahyangan Catholic University - Bandung, Indonesia \\ ${ }^{3}$ Professor, Brawijaya University - Malang, Indonesia
}

\begin{abstract}
Bali as main tourist destination in Indonesia has its attraction in customs, arts, culture, and nature. The efforts to make the culture of Bali (including its architecture) to be tourism commodity has been started since colonial time through "Baliseering", and continued in the era of New Order with "Tourism-Culture" and recently conducted in the twenty first century with "Ajeg Bali". At this present, it cannot be denied that the welfare of the society in Bali including the relativesof "Puri" mainly rely on tourism. Puri is the palace and the center of government during the era of kingdom in Bali. Up to this present, puri still has essential and urgent role towards the society since 1967, Puri Anyar Kerambitan in Tabanan has conducted tourism activities such as royal wedding, royal dinner, art performance \& exhibition, guesthouseand many others. This condition resulted on the sustainability and changes of architecture of puri as heritage of architecture from the past in terms of function, lay out, and shape of the building. This research is designed with qualitative method with the approach of case study. It will examine about the effort to maintain the existence of puri in present time and in the future as factual and interesting issue for the development of local and national architectural science especially in relation to social and cultural development of Bali society. In a wider extent, this research can be the entry point for the development of traditional architecture in Indonesia by considering the diversity of social and cultural aspect of ethnical community in Indonesia.
\end{abstract}

Keywords: tourism, sustainability and change, architecture, puri

\section{INTRODUCTION}

Bali has been famous with its beautiful nature, culture, art and customs that are closely related with Hindu religion. Since Dutch colonial time or around 1900s, Bali was treated just like a 'white paper' to project the fantasy and fear of colonizer about the degradation and extinction of Balinese culture and tradition, which is called "Baliseering". The Dutch Colonial functionalizes the tradition and culture of Bali in political, economical and cultural aspect through its colonial capitalism system. The practice of power is then continued after the independence of Indonesian Republic for around 30 years $(1970-2000)$ especially in the era of New Order through the program of tourism culture development. In the beginning of the twenty first century, a new movement emerge as cultural movement for inheriting, liquidating, and maintaining Balinese culture or popular as Ajeg Bali.

Puri functions as the palace for king and also center or government in Bali. The existence of puri was discovered since the fourteenth up to early twentieth century such as architectural heritage that is rich with diversity and variousness of architecture. Generally, Puri is located in the upper stream (the main concept: Kaja-Kangin) in the center of village of area with the pattern of pempatan agung or catus patha, that is formed by two crossing streets i.e. eastwest and north-south. The yard puri generally consists of three parts of spaces(tri mandala), i.e.: jaba sisi, jaba tengahandjeroan. The architectural design of puri is made based on the philosophy and conception of Bali Traditional Architecture (BTA) such astrihita karana, pempatan agung, nawasanga, natah, and triangga. The functions of puri as the residence of king, center of Balinese culture is considered essential and urgent from the past up to this present. The buildings of puri were designed for particular purpose and function that makes them become landmark of certain area.

The independence of Indonesia in 1945 with the concept of United State of Indonesian Republic or NKRI led to some changes towards the kingdoms in Bali. The king no longer possesseslegality aspect of political power, and the kingdom's assets of land decreased in number because of the implementation of land reform. The change does not influence the relation between king and the people. The people often visit puri to get advice, suggestion, and assistance from the relatives of puri in relation to religious and cultural rituals. Nowadays, there aretwo main functions and roles of puri.They are(1) tangible; as the center and power of community in dealing with customs, tradition, and material, and (2) intangible; as the gathering place of royal family with the spiritual leader that provided spiritual guidance and Hindu religion ritual and other general information such as knowledge and science that guide the life of the community. Puri is the representation of cultural and spiritual root of Bali society. It is only in puri, people can see activities of religious ritual, spirituality, and various forms of culture that is practice well. It is not surprising that the buildings or architecture of puri is also functional 
reflection of various need of ritual and cultural for Balinese (Kerthyasa in Mann, 2012).

The development of Bali to become tourist destination area in Indonesia reached its peak after 1970s. The family of Puri Anyar Kerambitan in Tabanan uses the opportunity of tourism by making modification, adaptation and even by changing the function and physical feature of Puri. Some tourist activities that can be done in puri are guest house/home stay; royal dinner, royal wedding, art or dance performance e.g. kecak dance, legong dance, art gallery,visiting building objects; training for teaching arts, research, and many others. The influence of tourism towards sustainability and change of architecture of puri building will be examined based on Balinese TraditionalArchitecture (BTA)such astri hita karana, pempatan agung, nawa sanga, natahandtri angga. The finding of this research is expected to contribute to the efforts of maintaining Balinese culture, especially the architecture of puri at this present and for the future.

\section{METHODOLOGY}

This research is designed with qualitative method with the approach of case studies. Some considerations to take qualitative research are (1). This method is considered easier to adapt with multiple realities; (2). This method can directly explain the philosophy of relations between researcher and respondents, and (3). This method is more sensible and adaptive with more emphasis to the patterns of values being faced.

Creswell (1998) explained that case study is a process in research that can be conducted in depth and holistic to examine a case by following particular structure as stated by Lincoln and Guba (1985) i.e.problem, context, issue, and learning points. In other words, case study research tries to propose contemporary theories. Cases study research used existing theories as the reference to determine the position of research result.

\section{RESULT AND DISCUSSION}

\subsection{Analysis on Function and Activities (Tri Hita}

\section{Karana)}

Tourism activity was started and accepted by the family of Puri Anyar Kerambitan since 4 July 1967, which can be traced from a plaque made on a river rock that can be physically found in thepalebahan ancak sajiof Puri Anyar Kerambitan. In the beginning, puri only became object of tourists visit and in around 1970, puri has started to welcome groups of foreign tourist from some countries in Europe. With the increasing interest and number of packages, the family of puri offered activities such as royal dinnerandart performance, especially foreign tourist. The visitors (nyama tamiu)is welcomed like the guest of king. They also got royal dinner and see some art performancessuch as traditional dance.The active participation of the community in helping from the preparation up to the completion of the program are doing activities such as cleaning the yard, preparing art performance, arranging the seats of the guests, making decoration for everypalebahan, beautifying the building, cooking, preparing food and presenting drinks dancing, playing gamelan, and many others.
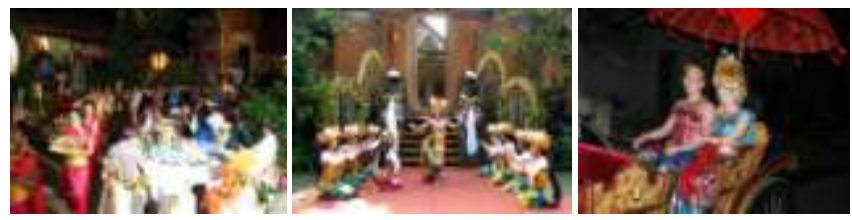

Fig -1 :Royal dinner, royal wedding and art performance Source: Documentation of Puri Anyar Kerambitan, Tabanan

Art performance is conducted during royal dinner with legongas welcoming dance for the guests, tek-tekan arts (unique art from Kerambitan) similar tokecak dancewith bamboo music instruments that resemble bamboo drum with some fragments of particular stories from the story ofRamayana. The last partis joged bumbung, which is a kind of dance to warm up the situation and for ice breakingto invite the tourist to participate dancing. Usually female dancer will invite both male and female guests to dance. This kind of programs received extraordinarily positive response and made the visit to Kerambitan increasing and more new request coming such as request of guest house and request for conducting royal wedding. The family of puri fulfilled the request (figure 1) but still keeps the balance of cosmology based on ethics, customs, culture, and the teaching of Hindu religion as the actualization of tri hita karana, which is relation between human and God, human and another human, and human and the nature.

The tourism dynamics of puri anyar Kerambitan reached its peak in the beginning of 1990s. Many world and national figures visited the place at that time. However, the glorious time of Puri Anyar Kerambitan could not survive anymore after its weakening reputation before 2000. In addition, terrorism attack of Bali Bombing I and II also deteriorate tourism condition that brings direct impact of declining tourism activities in Bali including Kerambitan. The degradation and deteriorating of tourism in Bali, made the big family of puri anyar worried, especiallyAnak Agung Putra Girisurya (Tojoes)a son in the family who is now responsible as the heir of puri with art spirit and likes painting (figure 2). At this present, the number of tourists visiting puri is very low and they only come to see the physical condition of puri anyar in a relatively short time. That is the statement ofAnak Agung Rai Giri Gunadhias thepenglisir of puri. The condition make their income may decrease and the physics of the building look bad and not maintained well.

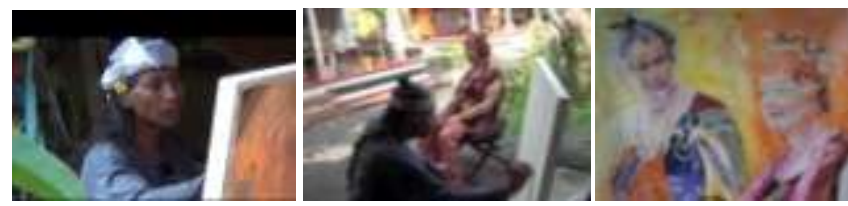

Fig -2 : Anak Agung Putra Girisurya (Tojoes) who loves painting

Source : Documentation of Puri Anyar Kerambitan, Tabanan 


\subsection{Analysis of Location and Lay Out of Puri} (Pempatan Agung)

Puri anyar is located in the intersection of main road in Kerambitan Village, Bali. It is known with the term Pempatan Agung or Catus Patha. Pempatan Agungis a pattern of crossbar(tapak dara)which is meeting point of two roads that is directed to each point of direction (northsouth and east-west) that symbolize earth and swastikaas a sign of luck. From the vacuum room (airless), the meeting result of the fourth side of the roads is then used to determine the position for the residence of the power holder or authority of State or Kingdom of Puri. In the center of the King City, puri is constructed along with other supporting facilities.

In Kerambitan Village, there are two Puri buildings which are located close to each other. The construction was started by building Puri Agung orPuri Gede as the place of king as the highest power holder in the area, who stay in one of the corner of catus pathain the direction ofkaja-kangin(utama ning utama) or in the north east of the intersection. The main values or the greatness of a puri is determined by the kinds of facilities in the king city and the number of palebahan. Puri Anyar Kerambitan as the development of the main puri or expansion of palace or because of power division is located in the intersection or pempatan agungbut it does not use the location of kaja-kangin (utama ning utama). In fact, it is located in the southwest(kelod-kauh)of the intersection. The location of puri in the southwest (neriti)is a symbol of kala reksa, which is a good location for the location of puri because it has werdi merit that is place where togetherness (yasa), and dedication to country meet to reach glory, prosperity, welfare, and perfection (Putra, 1998).

\subsection{Analysis of Space Zone(Nawa Sanga / Sanga}

\section{Mandala)}

Building unitsofpuri is grouped in one yard called pelataran orpalebahan. Puri anyar Kerambitan consists of severalpalebahanthat is close to the concept of sanga mandalaornawa sanga. The number of palebahan is more thannine with composition of space division which is not very clear or strict. The border of palebahan is usually building or walls calledpenyengker. The name of palebahan in Puri Anyar Kerambitan arepalebahan ancak saji, petandakan, saren agung, saren kangin, saren kelod, saren kauh, saren tengah, saren kaja, jaba tengah pamerajan and pamerajan agung.

Nawasanga(figures 3 and 4) is a concept of space division orientation (direction) that describe the position of the nine Gods in the macrocosmos level, with God Shiva as the center while other eight God is illustrated in the asta dikpalakahat describe the whole direction that will protect the life of human being. In mythology, it is stated that Mahameru Mountain that is symbol of human being life. Everypalebahanis completed with gate, landscape, and circulation line. Palebahanis opened for tourists in some events such as palebahan ancak saji, jaba tengah, petandakan and saren tengah.

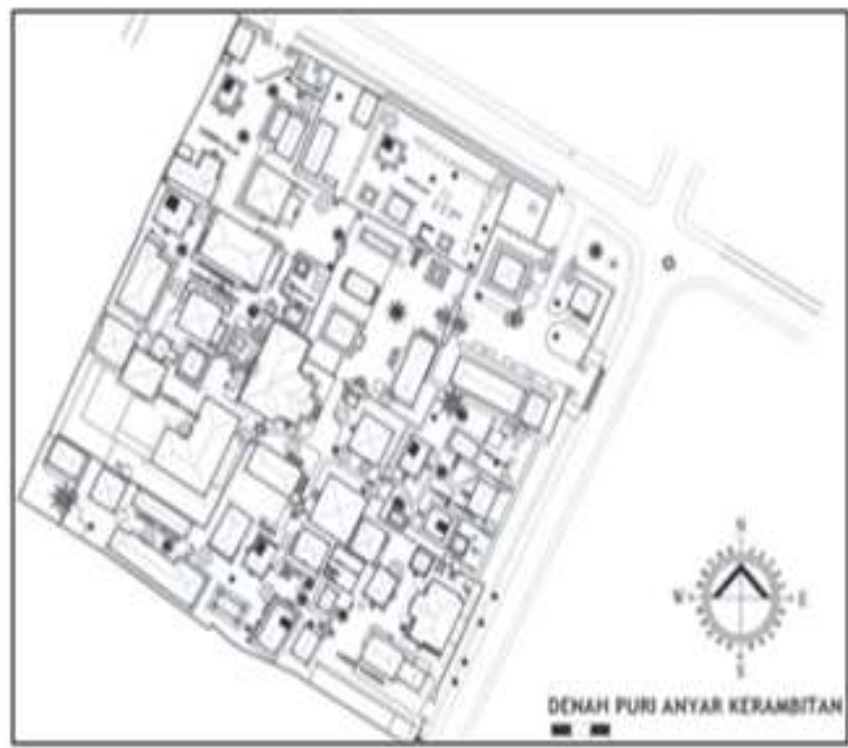

Fig -3 : Lay Out of Puri Anyar Kerambitan, Tabanan Source: Survey Result in Puri Anyar Kerambitan, Tabanan

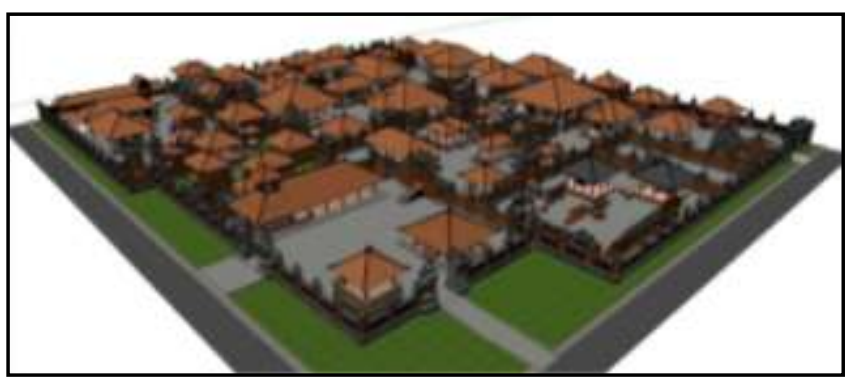

Fig -4: Perspectif of Puri Anyar Kerambitan, Tabanan

Source: Survey Result in Puri Anyar Kerambitan, Tabanan

\subsection{Analysis of Building Orientation( Natah)}

Orientation of building units in everypalebahan inPuri Anyar Kerambitan refers to the standard of resident building in Balinese Traditional Architecture (BTA). Most of the building units in every palebahan are oriented to the central yard called natah. Natah is anopen space with landscapewith various decorative plants such as ground cover, flowers, bush, clump, and shady plants. The design and layout of outdoor landscape can be considered as the form of architectural change that give aesthetics to the improvement of outdoor space function and comfort of interior in the surrounding building.
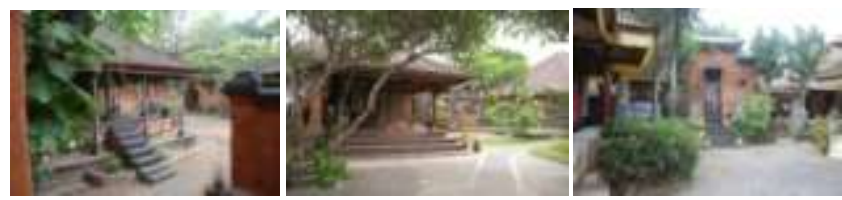

Fig -5: Natahinpalebahan saren agung (a), saren kaja (b) andjaba tengah pamerajan agung (c)

Source : Survey Results in Puri Anyar Kerambitan, Tabanan 


\subsection{Analysis of Rooms and Building (Tri Angga)}

In some buildings, several changes were found such as room addition and shape changing that still maintain the concept of Tri Anggathat consists of foot part (bhur loka), body part (bhuah loka)and head part(swah loka). The description can be seen in the space zone that can be accessed by tourist such as palebahan ancak saji, jaba tengah, petandakan andsaren tengah.In details, the examination on the change and sustainability of the building units are explained below:

\section{a. Palebahan ancak saji}

Palebahan ancak sajiis the front line of puri area. Nowadays, it is mostly used the place to welcome guest or tourist. In particular time, this place is also use for art performance, danceand religious or traditional events conducted by the family of puri. This tourism activity does not bring any impact to the physical condition of the building but only cause function addition such as meeting space orbale pertemuanandperformance stage or pementasanthat is used for place for practicing dancing and rest area for tourists.

\section{b. Palebahan jaba tengah}

Palebahan jaba tengahis part of holy area from palebahan pamerajan agung. The holy area consists of threepalebahannamely palebahan jaba sisi, jaba tengahandjeroan. The location of palebahan jaba tengahis quite strategic so that when guests visitPuri Anyar Kerambitan, they will pass palebahan ancak sajiand kori agungto reach palebahan jaba tengah. From thispalebahan, guests can continue their journey topalebahan petandakan, pelebahan saren kaja, and palebahan jeroan pamerajan agung.

As transitional room or connecting room between palebahan, then any visitors in the puri will certainly pass palebahan jaba tengah. During tourism activities in Puri Anyar Kerambitan such as usual visit, royal dinnerandroyal wedding, this palebahanwill play significant role. This bring fatal impact such as additional function in the outdoor space and in some units of the building.

During event ofroyal weddingand royal dinner, palebahan jaba tengahand some other buildings are used for food table and outdoor eating space that used the outdoor space of palebahan jaba tengah. The existing buildings will be decorated as when the king welcomes the honorableguests to come and visit the puri.

Additional functions of outdoor space (natah)and some buildings does not cause significant changes among the existing building. There is room additionbecause of the addition of function of palebahan and the building. Therefore, it can be stated that the tourism activity does not cause significant impact towards architectural change.

\section{c. Palebahan petandakan}

In the beginning, palebahan petandakanfunctions as place for welcoming royal guest during religious ceremony(piodalan)by the family of puri such as manusa yadnyaorpitra yadnyaceremony (figure 6). Since the location is close to palebahan ancak sajiand due to some request of staying in puri by tourist, then two buildings were available in the palebehan that can be used as guest house.

The addition or changing of building function as place for tourist accommodation influence the change of space function and the addition of lavatory in the left and right side of the back side in the building. The addition of lavatory room does not influence the form and look of the building that maintain the loji style with the pattern of Balinese Traditional Architectural (BTA) that implement the concept of triangga. The room change happens for the function addition of interior with the elements or furniture to fill the room based on the need of new function as guesthouse such as spring bed, cupboard, table, chair, make up desk, lighting, TV table, guest chairs, and many others.

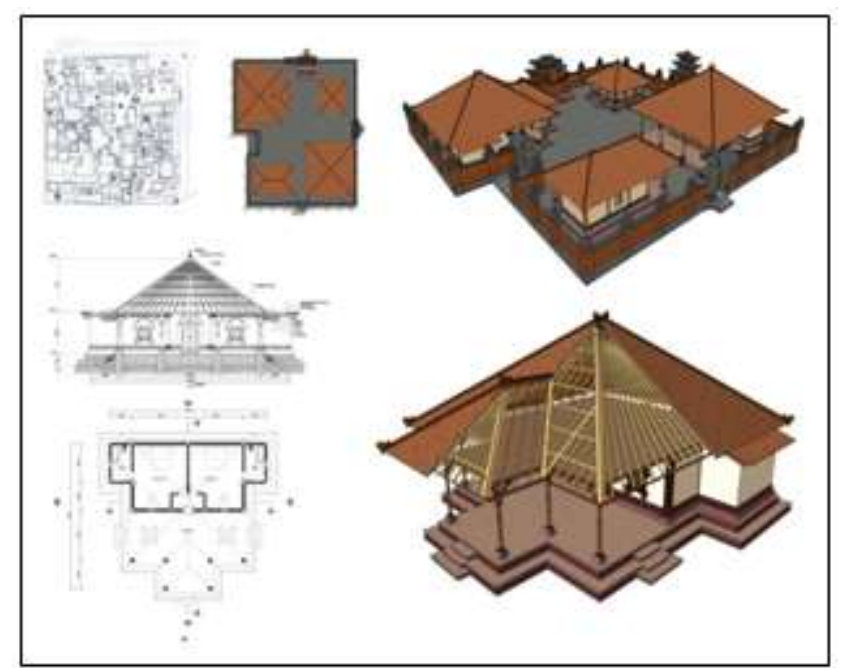

Fig -6: The Change of Building Function to become guest houseinpalebahan petandakan

Source: Survey in Puri Anyar Kerambitan, Tabanan

\section{d. Palebahan saren tengah}

Palebahan saren tengahin the past functions as the residence of kings' children or close relatives who are not in power.Recently, most of puri family does not stay in puri because along with the increasing popularity of Puri Anyar, Kerambitan, the request of accommodation from the tourist keep increasing. Thus, some building in palebahan saren tengahcan be used as guesthouse (figure 7).

Two buildings ofgedong or lojiare functioned as guest houseby maintaining the basic shape and size of the previous building. The result of house renovation with the new function as guest house is bed room building completed with lavatory plus a wide and large verandah. This building used the construction of 
concrete with muscle dominated by red and white brick with ornaments of grey rock that give artistic and aesthetics impression as the reflection of Balinese architecture. The pillar of the building from concrete with muscle is covered by exposed red brick completed with base on the bottom part. Meanwhile, the door and the window is surrounded by ornaments with the motif of part of plants such as flower, stem, and the leaves. The material of the ornament used grey rock that is mixed with red brick that will lead to the contrast of white wall. This will lead to the impression of beautiful frame that surround the door and the windows in the building.

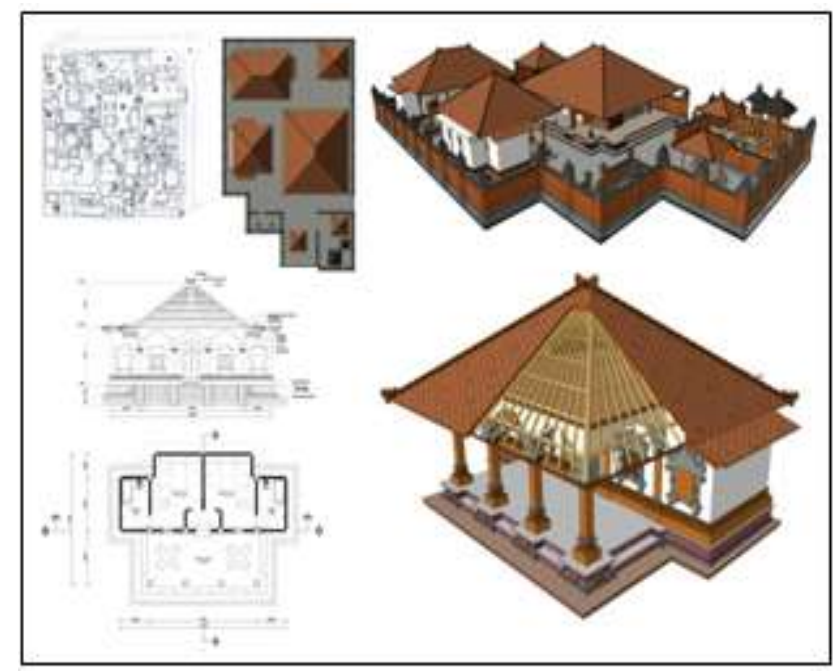

Fig -7: The change of building function to be guest houseinpalebahan saren tengah

Source : Survey in Puri Anyar Kerambitan, Tabanan

\section{CONCLUSION}

Bali with its cultural tourism developed since colonial time up to this present has tried to make some efforts to maintainthe potential and strength of Balinese culture as tourist attraction. However, tourism activity cannot negate the existence of Balinese culture. Puri Anyar Kerambitan, Tabanan has creatively designedthe puri as cultural tourist objects for the sake of its sustainability as cultural assets of Bali. The process of change and sustainability of Architecture is conducted by consistently maintaining the basic shape, size, and construction of the building based on the concept of Bali architecture that consists of tri hita karana, pempatan agung, sanga mandala, natah and triangga.

Tourism can give positive contribution in maintaining cultural building in Puri Anyar Kerambitan, Tabanan. The change and sustainability of architecture in nista zone are additional function as rest area and art performance, and royal wedding ceremony for tourists. Some units of building in madya or saren zone, has been changed to be guest house for tourists. However, function of other area in the puri with the building units in the main zone can be maintained for ritual and social activities especially for the family of puri.
The change and renovation of building (architecture) conducted by puri family indicate the luxury and charisma of Puri as the effort to maintain the existence of Balinese culture. The addition of rooms for tourist accommodation such as lavatory room and storage room is very minimalist compared to the size of the main building. Thus, it does not damage the existing pattern and it still represents the image of Balinese architecture.

\section{REFERENCES}

[1]. Agung, AnakAgungGde Putra (2005), PelestarianNilaiNilaiBudaya Daerah Demi KeutuhanBudayaBangsa, Kumpulan Artikel, FakultasSastraUniversitas Udayana, Denpasar

[2]. Appudurai, A (1993), Disjuncture and Difference in the Global Cultural Economy, dalam Featherstone, M (ed).1993, Global Culture, Nationalism, Globalization and Modernity, SAGE Publication, London

$\begin{array}{llr}\text { [3]. Ardhana, I GustiGede } & \text { (2005), } \\ \text { KearifanLokaldanKetahananBudaya } & \end{array}$ KearifanLokaldanKetahananBudaya
dalamPolitikKebudayaandanIdentitasEtnik,

FakultasSastraUniversitasUdayana, Denpasar

[4]. Ardika, I Wayan (2005), Strategi Bali MempertahankanKearifan Lokal Di Era Global, KompetensiBudayaDalamGlobaliasi, Kumpulan Artikel, FakultasSastraUniversitasUdayana, Denpasar.

[5]. Atmadja, NengahBawa (2010), AjegBali :Gerakan, IdentitasKulturaldanGlobalisasi, LKIS, Yogyakarta

[6]. Broadbent, G (1988), Design in Architecture, Fulton University of Virginia.

[7]. Budihardjo, Eko (1986),Architectural Conservation in Bali : Gajah Mada University Press, Yogyakarta

[8]. Ching, Francis D.K (1996), Architecture Form, Space And Order, John Wiley \& Sons, Inc, United States Of America.

[9]. Creswell, John W (1998), Qualitative Inquiry And Research Design : Choosing Among Five Traditions, Sage Publications, London.

[10]. Geertz, Clifford (1980), Negara The Theatre State In Nineteenth Century Bali, Princeton University Press, New Jersey, United Kingdom.

[11]. Gelebet, I Nyoman, et.al (1987).ArsitekturTradisional Daerah Bali :Depdikbud, Denpasar

[12]. Geriya, I Wayan (2000), TransformasiKebudayaan Bali Memasuki Abad XXI,DinasKebudayaanPropinsi Bali, Denpasar

[13]. Mann, Richard (2012). Palaces Of Bali : Gateway Books International

[14]. MacRae, Graeme (2005), Negara Ubud ?KerajaanBudaya Abad Globalisasi, dalamPolitikKebudayaandanIdentitasEtnik,

FakultasSastraUniversitasUdayana, Denpasar

[15]. Munandar, AgusAris (2005), Istana

DewaPulauDewata, MaknaPuri Bali Abad ke-14 s/d Abad ke-19, KomunitasBambu, Depok

[16]. Norberg-Schulz, Christian (1979), Genius Loci, Electe Rizolly, New York

[17]. Nordholt, Henk Schulte (2010),Bali Benteng Terbuka 1995-2005 :PustakaLarasan, Denpasar 
[18]. Putra, I Gusti Made (1998), Kekuasaan dan Transformasi Arsitektur - Suatu Kajian Budaya Terhadap Kasus Puri Agung Tabanan, Thesis Program Pascasarjana,

Fakultas Ilmu Budaya, Universitas Udayana, Denpasar

[19]. Rapoport, Amos (1969),House Form and Culture :Engelwood Cliffs, New York

[20]. Vickers, Adrian (2012), Bali Tempo Doeloe, KomunitasBambu, Jakarta.

\section{BIOGRAPHIES}

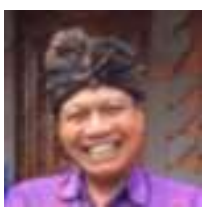

Rachmat Budihardjo, is doing his Doctoral Program Doktoral/S3 at Parahyangan Catholic University, Bandung, Indonesia

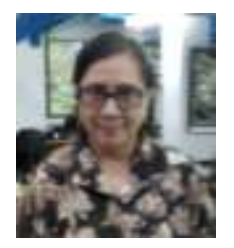

Rumiati R.Tobing, Post Graduate, Lecturer at Parahyangan Catholic University, Bandung, Indonesia.

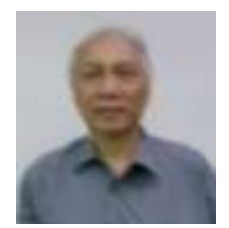

Antariksa, Profesor at Brawijaya University, Malang, Indonesia 